\title{
Fascial Fibrosarcoma
}

National Cancer Institute

\section{Source}

National Cancer Institute. Fascial Fibrosarcoma. NCI Thesaurus. Code C66765.

A malig nant fibroblastic neoplasm arising from the fascial connective tissue. 